\title{
O.O. ОСТРОВЕРХ
}

\section{СТАТИЧНЕ ДОСЛДЖЕННЯ ЕЛЕМЕНТІВ ТРЬОХВАЛЬНОЇ КОРОБКИ ПЕРЕДАЧ ЛЕГКОВОГО АВТОМОБІЛЯ 3 ПОПЕРЕЧНИМ РОЗТАШУВАННЯМ ДВИГУНА}

В роботі спроектовано трьохвальну коробку передач легкового автомобіля з поперечним розташуванням двигуна. Для визначення статичного дослідження елементів спроектованої трьохвальної коробки передач використовувався метод кінцевих елементів, який дає змогу досить повно врахувати геометричні форми та реальні умови роботи передач, розподілу зовнішніх навантажень, а також фізичні властивості використовуваних матеріалів. Для побудови тривимірної моделі зубчастих коліс використовувалось програмне середовище КОМПАС 3D V16. В якості розрахункової програми застосовано систему АРM FEM («Автоматичне Проектування Машин»), яка являє собою інтегрований в КОМПАС-3D інструмент для підготовки і подальшого кінцево-елементного аналізу тривимірної твердотільної моделі. Матеріал застосований стандартний сталь 3 невисокими характеристиками міцності, який дозволить при збільшенні навантажень надалі застосувати більш високоміцні сталі. Створення сітки кінцевих елементів проводилось у відповідності зі стандартним алгоритмом. Тривимірні моделі шестерень розбиті на кінцеві елементи, що дозволить з високою точністю провести їх розрахунок. Для збільшення продуктивності модель була спрощена, виконано виключення з розрахунку деяких елементів (фасок, отворів, округлень), які не чинять значного впливу на міцність. Кріплення деталі виконано по внутрішніх отворах деталей. На відміну від класичного розрахунку на міцність зубів, коли зусилля прикладається тільки до лінії контакту зубів, у даному розрахунку шестерень максимальний момент був прикладений до всієї робочої поверхні зуба. Вихідними даними по навантаженні шестерні служить максимальний крутний момент створюваний на валу двигуна.

Виходячи $з$ отриманих результатів, можна сказати, що навантаження розподіляється по довжині зуба нерівномірно. Найбільші напруги виникають зі сторони прикладання навантаження до кромки зуба, а також у середній і нижній ніжки сполучення ії з зубчастим вінцем. Різний розподіл зусиль на всій поверхні шестерень пов'язано, з різними кутами профілю вихідного контуру зубів.

Також був виконаний розрахунок коефіцієнту запасу текучості та міцності, та розраховане максимальне переміщення. В результаті проведених розрахунків по запасу міцності і текучості, невеликі показники у шестерні постійного зачеплення пов'язано з тим, що зусилля для розрахунку було докладено до однієї кромки. 3 огляду на те, що при роботі шестерні в зачепленні будуть знаходитися всі зуби, сумарно коефіцієнт запасу міцності, і текучості буде порівнянний з шестернею п'ятої передачі. Додаток зусилля до однієї кромки виконано для спрощення розрахунку.

Аналіз розрахунку власних частотних коливань і кутових (циклічних частот), показав їх незначний вплив на деталі і механізми при конструюванні коробки передач.

Ключові слова: автомобіль, коробка передач, шестерня, статичне дослідження, сітка кінцевих елементів, тривимірна модель.

\section{A.O. OCTPOBEPX}

\section{СТАТИЧЕСКОЕ ИССЛЕДОВАНИЕ ЭЛЕМЕНТОВ ТРЕХВАЛЬНОЙ КОРОБКИ ПЕРЕДАЧ ЛЕГКОВОГО АВТОМОБИЛЯ С ПОПЕРЕЧНЫМ РАСПОЛОЖЕНИЕМ ДВИГАТЕЛЯ}

В работе спроектировано трьохвальну коробку передач легкового автомобиля с поперечным расположением двигателя. Для определения статического исследования элементов спроектированной трехвальной коробки передач использовался метод конечных элементов, который позволяет достаточно полно учесть геометрические формы и реальные условия работы передач, распределения внешних нагрузок, а также физические свойства используемых материалов. Для построения трехмерной модели зубчатых колес использовалось программное среду КОМПАC 3D V16. В качестве расчетной программы применена система APM FEM («Автоматическое Проектирование Машин»), которая представляет собой интегрированный в КОМПАС-3D инструмент для подготовки и дальнейшего конечно-элементного анализа трехмерной твердотельной модели. Материал применен стандартный сталь с низкими прочностными характеристиками, который позволит при увеличении нагрузок в дальнейшем применить более высокопрочные стали. Создание сетки конечных элементов проводилось в соответствии со стандартным алгоритмом. Трехмерные модели шестерен разбиты на конечные элементы, что позволит с высокой точностью провести их расчет. Для увеличения производительности модель была упрощена, выполнено исключения из расчета некоторых элементов (фасок, отверстий, округления), которые не оказывают значительного влияния на прочность. Крепления детали выполнено по внутренним отверстиях деталей. В отличие от классического расчета на прочность зубов, когда усилие прикладывается только к линии контакта зубьев, в данном расчете шестерен максимальный момент был приложен ко всей рабочей поверхности зуба. Исходными данными по нагрузке шестерни служит максимальный крутящий момент создаваемый на валу двигателя.

Исходя из полученных результатов, можно сказать, что нагрузка распределяется по длине зуба неравномерно. Наибольшие напряжения возникают из стороны приложения нагрузки к кромке зуба, а также в средней и нижней ножки сообщения ее с зубчатым венцом. Разное распределение усилий на всей поверхности шестерен связано с различными углами профиля исходного контура зубов.

Также был выполнен расчет коэффициента запаса текучести и прочности, и рассчитано максимальное перемещение. В результате проведенных расчетов по запасу прочности и текучести, небольшие показатели в шестерни постоянного зацепления связано с тем, что усилия для расчета были приложены к одной кромки. Учитывая то, что при работе шестерни в зацеплении будут находиться все зубы, суммарно коэффициент запаса прочности, и текучести будет сравним с шестерней пятой передачи. Приложение усилия к одной кромки выполнено для упрощения расчета.

Анализ расчета собственных частотных колебаний и угловых (циклических частот), показал их незначительное влияние на детали и механизмы при конструировании коробки передач.

Ключевые слова: автомобиль, коробка передач, шестерня, статическое исследование, сетка конечных элементов, трехмерная модель

\section{A.O. OSTROVERKH}

\section{STATIC RESEARCH OF THE ELEMENTS OF A THREE-SINGLE PASSENGER TRANSMISSION WITH TRANSVERSE LOCATION OF THE ENGINE}

The design of the three-shaft gearbox of the car with the transverse arrangement of the engine is designed. To determine the static study of the elements of the designed three-wave gearbox, the finite element method was used, which allows to take into account the geometric forms and 
real conditions of transmission, the distribution of external loads, as well as the physical properties of the materials used. The COMPASS 3D V16 software environment was used to build the 3D gear model. APM FEM ("Automatic Machine Design") system, which is an integrated in COMPASS-3D tool for preparation and further finite element analysis of a three-dimensional solid model, is used as the calculation program. The material is a standard steel with low strength characteristics, which will allow the use of higher strength steels with increasing loads. The finite element grid was created according to the standard algorithm. Three-dimensional models of gears are divided into finite elements, which will allow them to calculate with high accuracy. To increase productivity, the model was simplified, exceptions were made for some elements (chamfers, holes, rounding) that do not have a significant effect on durability. Fastening of a part is made on internal openings of details. Unlike the classic calculation of dental strength, when the force is applied only to the tooth contact line, in this calculation, the maximum torque was applied to the entire working surface of the tooth. The output of the gear load is the maximum torque created on the motor shaft.

Based on the obtained results, we can say that the load is distributed along the length of the tooth unevenly. The greatest stresses arise from the side of application of the load to the edge of the tooth, as well as in the middle and lower legs of pairing it with the gear crown. Different effort distribution over the entire surface of the gears is associated with different angles of the profile of the original contour of the teeth.

Also, the calculation of the coefficient of fluidity and strength, and the maximum displacement was calculated. As a result of the calculations for the margin of safety and fluidity, the small figures in the gear of constant engagement are due to the fact that the efforts for the calculation were made to one edge. Given that the gear will be engaged in the gearing will be all the teeth, the total factor of safety, and the fluidity will be comparable to the gear of the fifth gear. One-edge effort is made to simplify the calculation.

Analysis of the calculation of the natural frequency oscillations and angular (cyclic frequencies), showed their small influence on the details and mechanisms in the design of the gearbox.

Key words: car, gearbox, gear, static study, finite element grid, three-dimensional model.

Вступ. Коробка передач являє собою механізм, шестерні котрої утворюють зубчасті пари, які можна тим або іншим чином по черзі вмикати і вимикати змінюючи, таким чином, передавальні числа.

Найважливішими показниками, що характеризують коробку передач є число передач і діапазон передавальних чисел.

Діапазоном передавальних чисел коробки передач називається відношення найбільшого і найменшого їх значень. Чим різноманітніші дорожні умови, для яких призначений автомобіль, і чим менше питома потужність його двигуна, тим більше повинен бути діапазон передавальних чисел коробки передач. Число передач прямо пов'язане $з$ діапазоном передавальних чисел (чим він ширше, тим більше передач в коробці). На число передач впливає не тільки тип автомобіля і потужність його двигуна, а й характер протікання швидкісних характеристик [1].

Аналіз останніх досліджень і публікацій. Найбільш поширеними конструктивними схемами механічних коробок передач $є$ двохвальна i трьохвальна коробки. На автомобілях класичної схеми зазвичай застосовують трьохвальні коробки передач. Особливістю режиму роботи автомобілів $\epsilon$ те, що у них майже завжди можна виділити передачу, на якій вони проходять більшу, іноді переважну частину шляху. Тому основною перевагою трьохвальних коробок $\epsilon$ наявність в них так званої прямої передачі, що виходить при безпосередньо з'єднанні первинного валу i вторинного валів. В цьому випадку шестерні, підшипники i проміжний вал практично звільняється від навантажень, а первинний i вторинний передають тільки крутний момент. Знос і шум коробки при цьому мінімальні, а коефіцієнт корисної дії - ККД близький до одиниці. Іншою перевагою трьохвальних конструкцій $\epsilon$ відносна легкість отримання великого передавального числа на першій передачі при малій міжосьовій відстані. Це пояснюється тим, що передавальне число всіх передач, крім прямої, у таких коробок утворюється двома послідовно працюючими парами шестерень, на відміну від однієї пари двохвальної конструкцій.
Двохвальні коробки передач простіші, дешевші і мають більш високий ККД (тільки на прямій передачі трьохвльна коробка має більш високий ККД, ніж двохвальна). Однак вирішальною перевагою двохвальної коробки передач $\epsilon$ простота виведення крутного моменту на будь-яку сторону коробки (передню або задню або на обидві відразу), що в деяких випадках, наприклад при задньомоторних, передньопривідних i повнопривідних конструктивних схемах автомобілів, представляє великі компонувальні можливості. Трьохвальні коробки для виведення крутного моменту з тієї ж сторони картера, з якої він був підведений, доводиться робити більш складними і менш технологічними, i такі конструкції використовують вкрай рідко [2-6].

Мета дослідження, постановка задачі. Метою роботи є статичне дослідження елементів спроектованої трьохвальної коробки передач легкового автомобіля 3 поперечним розташуванням двигуна.

Кінематична схема трансмісії автомобіля. Для побудови нової трьохвальної коробки передач, спроектовано іiі кінематичну схему (рис. 1), яка складається 3: двигуна - A, муфти зчеплення - Б, механічної коробки передач - В, головної передачі з диференціалом - Г, заднього ходу - ЗХ. Після побудови кінематичної схеми механічної коробки передач, розроблено складальний кресленик нової коробки передач (рис. 2), який буде встановлюватися на передньопривідний легковий автомобіль 3 поперечним розташуванням двигуна.

В ході роботи спроектовано трьохвальну шести ступеневу коробку передач з передаточним числом одиниця на п'ятій передачі.

Принцип роботи спроектованої коробки передач. Розроблена трьохвальна коробка передач працює, як в двохвальному, так і в трьохвальному режимах роботи, які відрізняються від класичних механічних коробок передач. При включенні п'ятої передачі вона працює в трьохвальному режимі. У всіх інших режимах в двохвальному режимі, але при цьому немає прямої передачі, як в класичному його розумінні. Так як момент передається від вхідного на проміжний вал як на 
прямій передачі, а передавальне число створюється за рахунок передачі моменту від проміжного валу до вихідного. До особливостей можна віднести відсутність необхідності установки шестерні на шліцьовому з'єднанні на вихідному валу, так як коробка передач працює в різних режимах при включенні п'ятої і всіх інших передач.

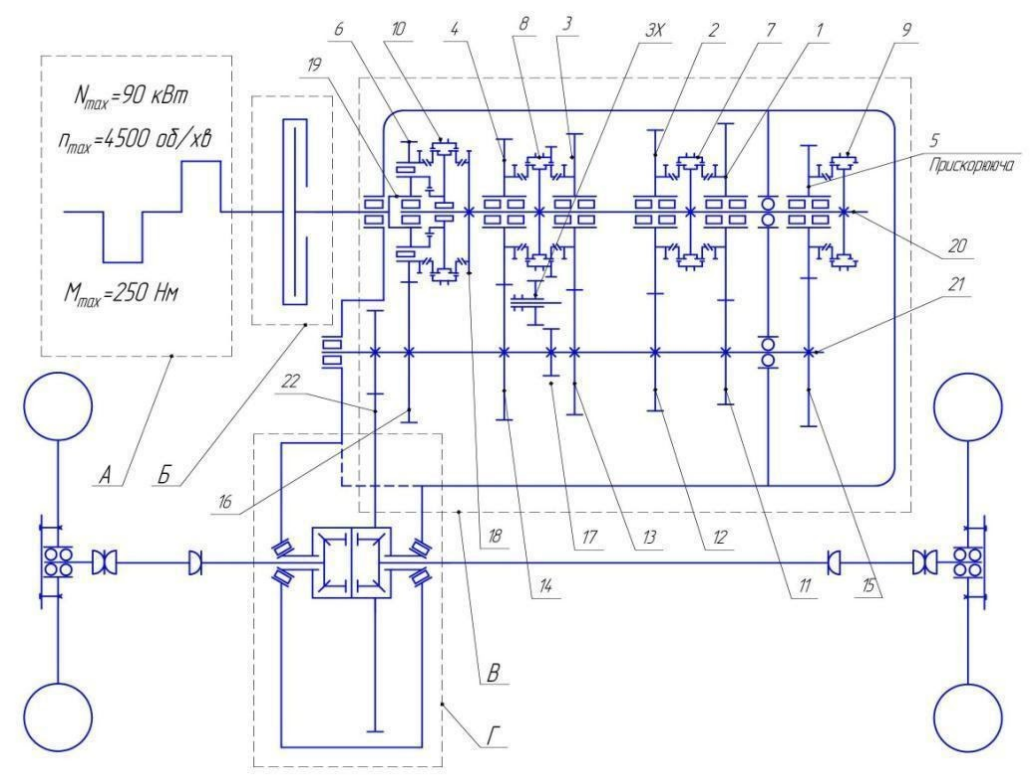

Рис. 1. Кінематична схема трансмісіїі автомобіля з поперечним розташуванням двигуна та розробленою трьохвальною коробкою передач:

1 - ведуча шестерня першої передачі; 2 - ведуча шестерня другої передачі; 3 - ведуча шестерня третьої передачі;

4 - ведуча шестерня четвертої передачі, 5 - ведуча шестерня шостої передачі; 6 - ведуча шестерня п'ятої передачі;

7 - синхронізатор першої другої передачі; 8 - синхронізатор третьої четвертої передачі; 9 - синхронізатор шостої передачі; 10 - синхронізатор п'ятої передачі; 11 - ведена шестерня першої передачі; 12 - ведена шестерня другої передачі; 13 - ведена шестерня третьої передачі; 14 - ведена шестерня четвертої передачі; 15 - ведена шестерня шостої передачі; 16

- ведена шестерня п'ятої передачі; 17 - ведена шестерня заднього ходу; 18 - шестерня постійного зачеплення; 19 первинний вал; 20 - проміжний вал; 21 -вторинний вал; 22 - шестерня диференціалу; $3 \mathrm{X}$ - паразитна шестерня заднього ходу.

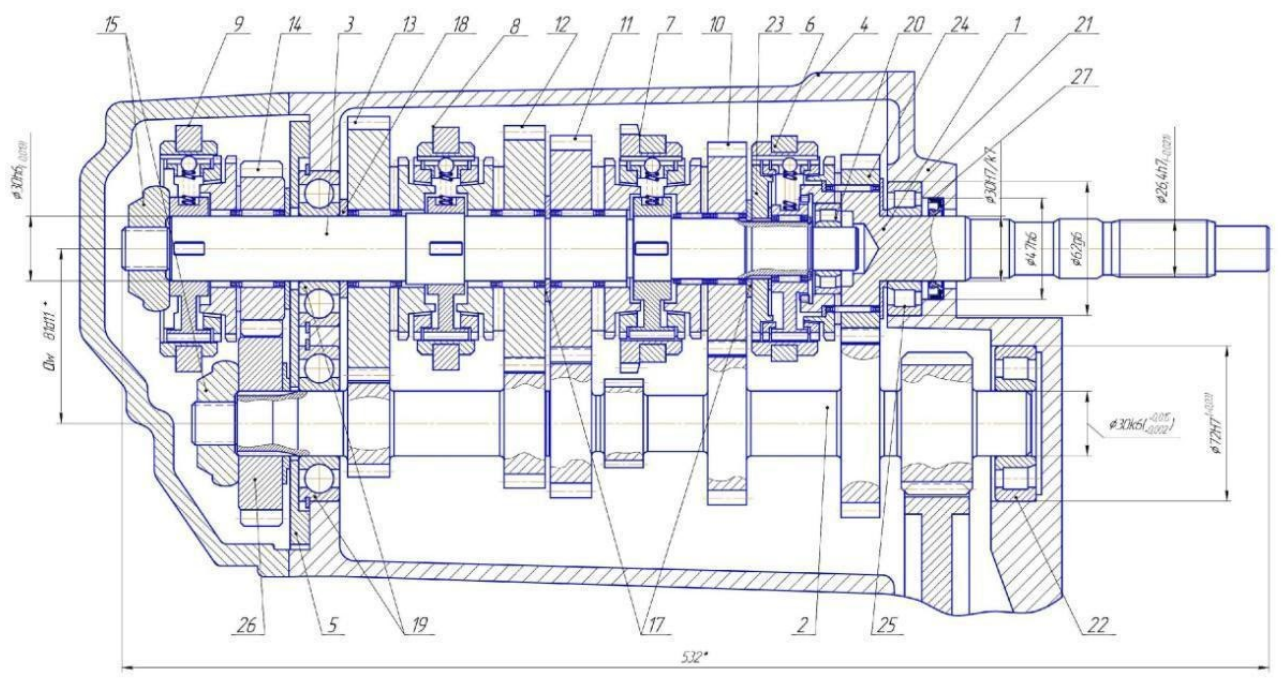

Рис. 2. Складальний кресленик розробленої трьохвальної коробки передач:

1 - вал первинний; 2 - вал вторинний; 3 - вал проміжний; 4 - картер коробки передач; 5 - кришка;

6 - синхронізатор п’ятої передачі; 7 - синхронізатор першої та другої передачі; 8 - синхронізатор третьої та четвертої передачі; 9 - синхронізатор шостої передачі; 10 - шестерня першої передачі; 11 - шестерня другої передачі;

12 - шестерня третьої передачі; 13 - шестерня четвертої передачі; 14, 26 - шестерні шостої передачі; 15 - гайка; 16 - блок шестерня заднього ходу (на рисунку відсутня); 17 - стопорне кільце, 18 - втулка; 19, 20, 22, 25 - підшипник; 21 - картер диференціалу; 23 - шестерня постійного зачеплення; 24 - шестерня п’ятої передачі, 27 - манжета. 
Розглянемо принцип роботи при увімкненій першій передачі: крутний момент від двигуна внутрішнього згоряння передається на первинний вал 1, синхронізатор 6, шестерню постійного зачеплення 23 на проміжний вал 3 , синхронізатор 8, шестерню першої передачі 13, вторинний вал 2 і далі на ведучі колеса автомобіля. Коробка працює по принципу двохвальної коробки передач.

Увімкнена п'ята передача, 3 передаточним числом одиниця, в коробці передач. Крутний момент від двигуна внутрішнього згоряння передається на первинний вал 1, синхронізатор 6, шестерню 24 , вторинний вал 2 і далі на ведучі колеса автомобіля. Коробка працює, по принципу трьохвальної коробки передач.

Спроектована коробка передача представляє собою інтерес оскільки має конструктивні особливості як трьохвальної так і двохвальної коробок передач.

Статичне дослідження шестерень постійного зачеплення та п'ятої передачі проектованої трьохвальної коробки передач. В роботі виконано дослідження напружено-деформованого стану шестерні постійного зачеплення 23 і п'ятої передачі 24 (рис. 3), спроектованої трьохвальної коробки, для цього використовувався метод кінцевих елементів, який дає змогу досить повно врахувати геометричні форми та реальні умови роботи передачі, розподілу зовнішніх навантажень, а також фізичні властивості використовуваних матеріалів. Поломка зуба, найбільш небезпечний вид руйнування, призводить не тільки до виходу 3 ладу передачі, але i до руйнування інших деталей приводного механізму (валів, підшипників), розрізняють поломки виснажливого характеру, пов'язані 3 дією змінних напруг, i поломки від перевантажень. У першому випадку тріщини втоми з'являються в ніжки зуба з боку розтягнутих волокон. Основними причинами поломки від перевантажень $є$ : нерівномірний розподіл навантаження по довжині зуба, пов'язане 3 виготовленням і деформаціями зубів, валів і опорних пристроїв; абразивний знос, що призводить до ослаблення зуба в небезпечному перерізі і додатковим динамічним навантаженням в зачепленні. При поломці зуба прямі короткі зуби виламуються повністю по перетину біля основи зуба. Зуби шевронних і широких косозубих коліс руйнуються по косому перетину. При втомному руйнуванні на тілі колеса залишається увігнута, а при поломці від перевантаження - опукла поверхня.

Розрахунок деталей і вузлів механізмів і машин $\epsilon$ важливою складовою їх проектування i конструювання. Сучасні комп'ютерні технології дозволяють комплексно провести необхідні обчислення геометричних розмірів деталей і вузлів в залежності від ряду факторів: умов експлуатації, режимів роботи, вибраного матеріалу і т. д.

Метод кінцевих елементів $€$ найбільш поширеним методом вирішення широкого кола наукових та інженерних задач. Це пояснюється простотою понять МКЕ, властивою йому логічністю i ефективністю застосування. Ключова ідея МКЕ полягає в наступному: суцільне середовище (конструкція в цілому) замінюється дискретною шляхом розбиття іiі на області (кінцеві елементи), в кожній з яких поведінка середовища описується за допомогою окремого набору функцій, що представляють собою напруження і переміщення в зазначеній області. Кінцеві елементи з'єднуються вузлами. Взаємодія кінцевих елементів один з одним здійснюється тільки через вузли. Елементи розташовані певним чином в залежності від конструкції об'єкта і закріплені відповідно до граничних умов. Кінцеві елементи дозволяють адекватно описати все різноманіття конструкцій i деталей. Метод кінцевих елементів відноситься до варіаційних методів теорії пружності і дозволяє оцінювати напружено-деформований стан плоских i об'ємних елементів конструкцій. Профіль зубів будувався за допомогою програми КОМПАС 3D V16. В якості розрахункової програми обрана система APM FEM, яка являє собою інтегрований в КОМПАС-3D інструмент для підготовки і подальшого кінцево-елементного аналізу тривимірної твердотільної моделі (деталі чи складання) [7]. Підготовка геометричної 3D-моделі і завдання матеріалу здійснюється засобами системи КОМПАC-3D. За допомогою APM FEM можна прикласти навантаження різних типів, вказати граничні умови, створити, кінцево-елементну, сітку і виконати розрахунок. При цьому процедура генерації кінцевих елементів проводиться автоматично. Геометричні параметри зубчастих пар наведені в (табл. 1). Вихідними даними став попередній розрахунок по коробці передач, згідно 3 яким максимальне зусилля, що докладається до поверхні зуба складе $250 \mathrm{H} \cdot \mathrm{M}$.

Основні механічні властивості сталі представлені в (табл. 2), яка застосовується для обох зубів. Розбиття шестерень на кінцеві елементи проводиться у відповідності зі стандартним алгоритмом тетраедризації. Тривимірна твердотільна модель шестерні розбивається на певну кількість кінцевих елементів і вузлів зведених в табл. 3. Результати розбиття, фіксації та навантаження представлені на (рис. 4). Для отримання найбільш точних результатів виконувалося ущільнення сітки кінцевих елементів в зоні плями контакту до 0,1 мм, а по робочій поверхні зуба до 2 мм.

Для збільшення продуктивності при розрахунку були виконані виключення 3 розрахунку деяких елементів. До них відносяться фаски, канавки, невеликі отвори i інші об'єкти, які не чинять значного впливу на міцність, однак для їх коректного опису потрібно значне зменшення розмірів кінцевих елементів.

В (табл. 4) представлені характеристики досліджуваних зубів. Визначення напруг, що виникають в шестерні, виконувалися на ЕОМ методом кінцевих елементів за допомогою розрахункового комплексу APM FEM, широко застосовуваного в даний час для вирішення 
інженерних завдань. Моделювання напружено-деформованого стану проводимо при максимальному моменті, що виникає на вхідному валу коробки передач (рис. 5) і (табл. 5).

Визначення напруг, що виникають в шестерні, проводилися на ЕОМ методом кінцевих елементів за допомогою розрахункового комплексу АPM FEM, широко застосовуваного в даний час для вирішення інженерних завдань. Моделювання напружено-деформованого стану виробляємо при максимальному моменті, що виникає на вхідному валу коробки передач (рис. 6 та 7). Виходячи 3 отриманих результатів, можна сказати, що навантаження розподіляється по довжині зуба нерівномірно. Найбільші напруги виникають у правої кромки зуба, а також в середній і нижній ніжки сполучення іiі з зубчастим вінцем.

Розрахунок на лінійне переміщення показаний на (рис. 6), і дані зведені в (табл. 6). 3 результатів слідує те, що повне переміщення є сумою переміщень в результаті об'ємної і контактної деформацій зуба, причому ці переміщення $\epsilon$ переміщеннями одного порядку. 3 отриманих графічних епюр видно, що максимальні переміщення виникають на верхній кромці зубів під час виходу їх із зачеплення.

Таблиця 1 - Основні геометричні параметри зубчастих пар

\begin{tabular}{|c|c|c|c|}
\hline Параметр & Поз. & Шестерня 23 & Шестерня 24 \\
\hline Число зубів & $z$ & 40 & 2 \\
\hline Модуль, мм & $m$ & 2 & $21^{\circ} 59^{\prime} 59^{\prime \prime}$ \\
\hline $\begin{array}{c}\text { Кут нахилу зубів на ділильному } \\
\text { циліндрі }\end{array}$ & $\beta$ & $0^{\circ} 00^{\prime} 00^{\prime \prime}$ & 18 \\
\hline Ширина зубчатого вінця, мм & $b$ & 4 & $80,89(+0,02 ;-0,1)$ \\
\hline Міжосьова відстань, мм & $a_{w}$ & $81(+0,02 ;-0,1)$ & 81,968 \\
\hline Ділильний діаметр, мм & $d$ & 82 & 76,3 \\
\hline Основний діаметр, мм & $d_{b}$ & 77,055 & \\
\hline
\end{tabular}

Таблиця 2 - Механічні характеристики сталі

\begin{tabular}{|c|c|}
\hline Параметр & Значення \\
\hline Межа текучості [МПа] & 235 \\
\hline Модуль пружності нормальний [MПа] & 0,3 \\
\hline Коефіцієнт Пуассона & 7800 \\
\hline Щільність [кг/м³] & 0,000012 \\
\hline Температурний коефіціснт лінійного розширення [1/C] & 1 \\
\hline Теплопровідність [Вт/(м·С)] & 410 \\
\hline Межа міцності при стисненні [МПа] & 209 \\
\hline Межа витривалості при розтягуванні [МПа] & 139 \\
\hline Межа витривалості при крученні [МПа] & \\
\hline
\end{tabular}

Таблиця 3 - Параметри і результати розбиття

\begin{tabular}{|c|c|c|}
\hline \multirow{2}{*}{ Найменування } & \multicolumn{2}{|c|}{ Значення } \\
\hline & Шестерня 23 & Шестерня 24 \\
\hline Максимальна довжина сторони елемента, мм & 2 & 2 \\
\hline Максимальний коефіцієнт згущення на поверхні & 1 & 1 \\
\hline Коефіцієнт розрідження в обсязі & 1,5 & 1,5 \\
\hline Кількість кінцевих елементів & 23982 & 53640 \\
\hline Кількість вузлів & 7270 & 14861 \\
\hline
\end{tabular}



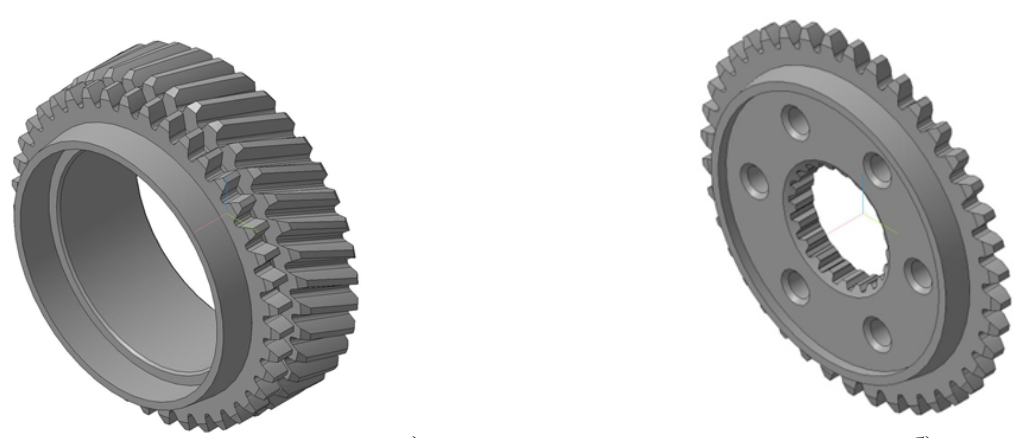

a)

б)

Рис. 3. Шестерні коробки передач:

а) шестерня постійного зачеплення; б) шестерня п'ятої передачі

Таблиця 4 - Інерційні характеристики моделі

\begin{tabular}{|c|c|c|}
\hline \multirow{2}{*}{ Найменування } & \multicolumn{2}{|c|}{ Значення } \\
\cline { 2 - 3 } & Шестерня 23 & Шестерня 24 \\
\hline Маса моделі [кг] & 0,231942 & 0,550849 \\
\hline Абсолютне значення реакції $[\mathrm{H}]$ & 322,953988 & 249,139075 \\
\hline Абсолютне значення моменту $[\mathrm{H} \cdot \mathrm{M}]$ & 9,764156 & 9,803312 \\
\hline
\end{tabular}

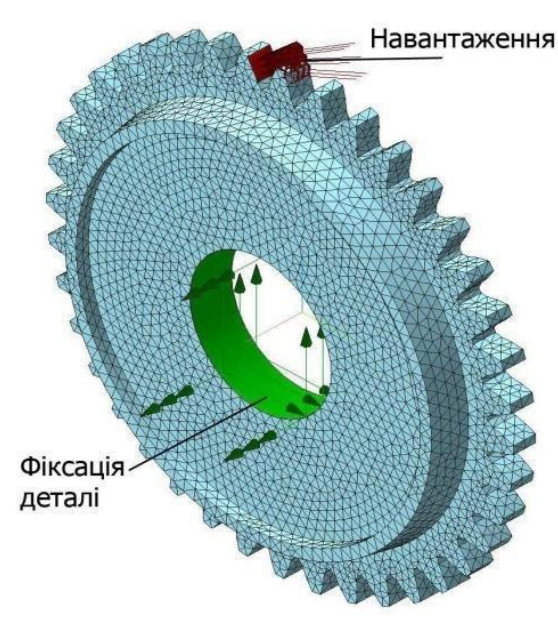

a)

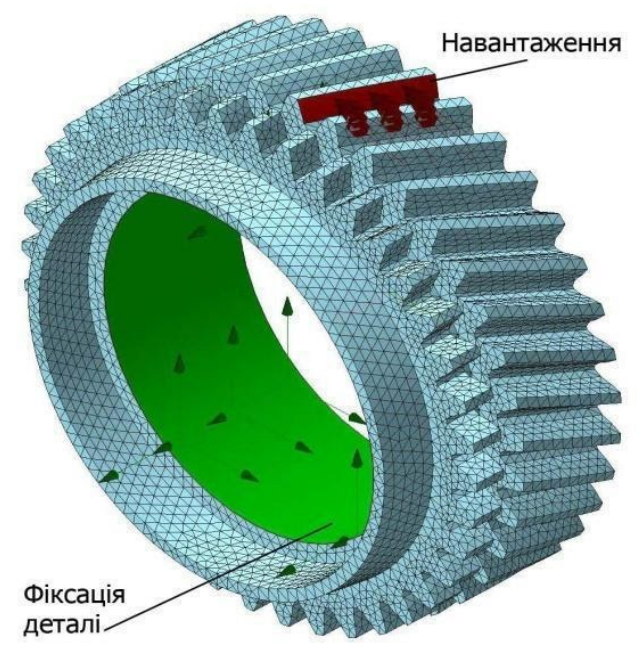

б)

Рис. 4. Кінцево-елементна сітка деталей із зображенням ступеней свободи, та прикладеної сили і напрямку: а) шестерня постійного зачеплення; б) шестерня п'ятої передачі

Таблиця 5 - Результати розрахунку по напрузі

\begin{tabular}{|c|c|c|c|c|c|}
\hline \multirow{2}{*}{$\begin{array}{c}\text { Найменування } \\
\text { Тип }\end{array}$} & \multicolumn{2}{|c|}{ Шестерня 23 } & \multicolumn{2}{|c|}{ Шестерня } \\
24 \\
\cline { 3 - 6 }
\end{tabular}




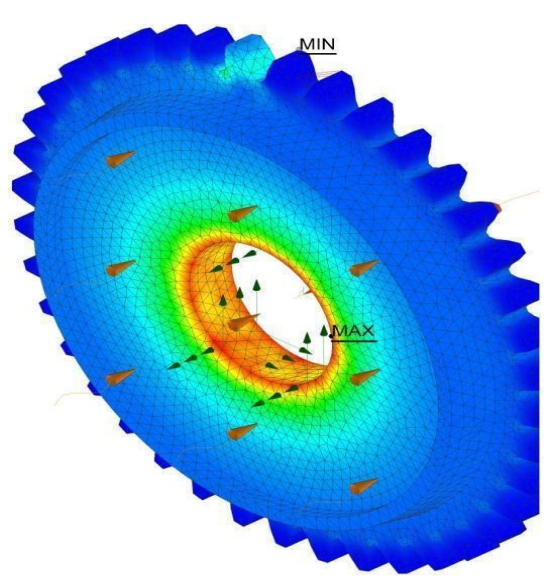

a)

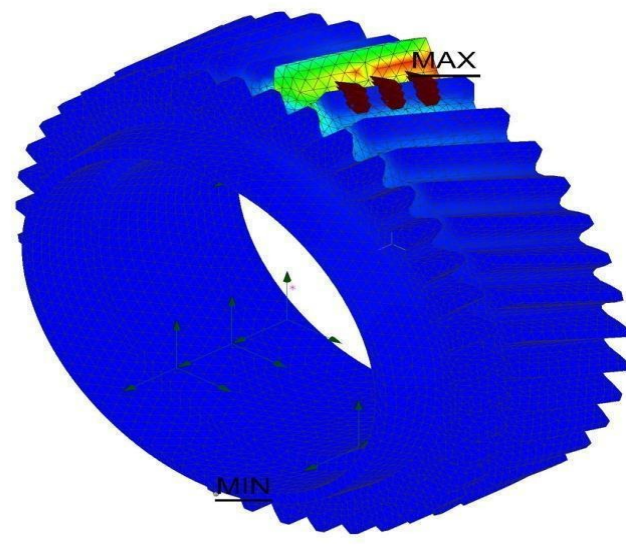

б)

Рис. 5. Розподіл механічних напруг в матеріалі шестерні при навантаженні робочої поверхні зуба: а) шестерня постійного зачеплення; б) шестерня п’ятої передачі

Таблиця 6 - Результати розрахунку на максимальні переміщення

\begin{tabular}{|c|c|c|c|c|c|}
\hline \multirow{2}{*}{ Найменування } & \multirow{2}{*}{ Тип } & \multicolumn{2}{|c|}{ Шестерня 23 } & \multicolumn{2}{|c|}{ Шестерня 24 } \\
\cline { 3 - 6 } & & Min & Max & Min & Max \\
\hline Сумарне лінійне переміщення & USUM [мм] & 0 & 0,009018 & 0 & 0,00045 \\
\hline
\end{tabular}

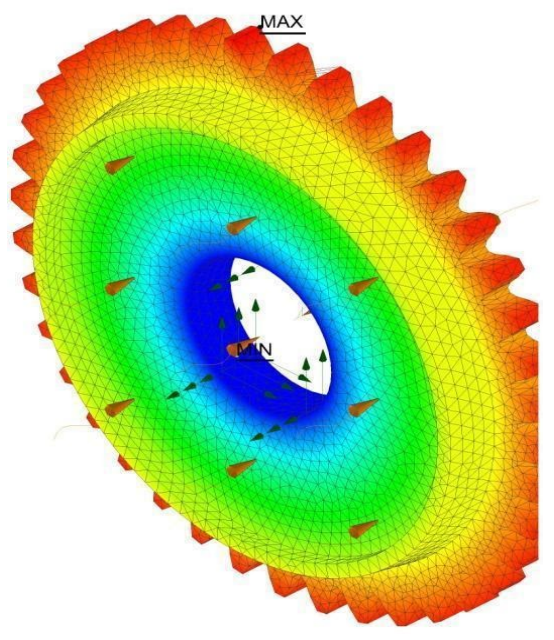

a)

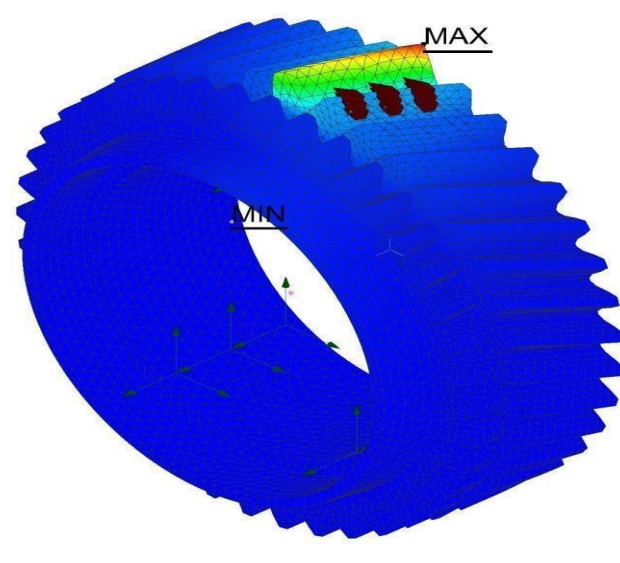

б)

Рис. 6. Переміщення зуба при додатку сили до його поверхні:

а) шестерня постійного зачеплення; б) шестерня п'ятої передачі

Таблиця 7 - Параметри коефіцієнта запасу по текучості

\begin{tabular}{|c|c|c|c|c|}
\hline \multirow{2}{*}{ Найменування } & \multicolumn{2}{|c|}{ Шестерня 23 } & \multicolumn{2}{|c|}{ Шестерня24 } \\
\cline { 2 - 5 } & Min & Max & Min & Max \\
\hline Коефіцієнт запасу по текучості & 2,641479 & 1000 & 40,001603 & 1000 \\
\hline
\end{tabular}




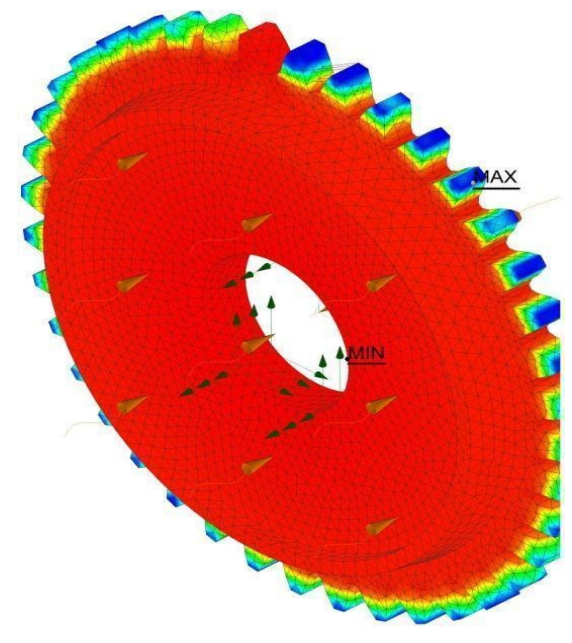

a)

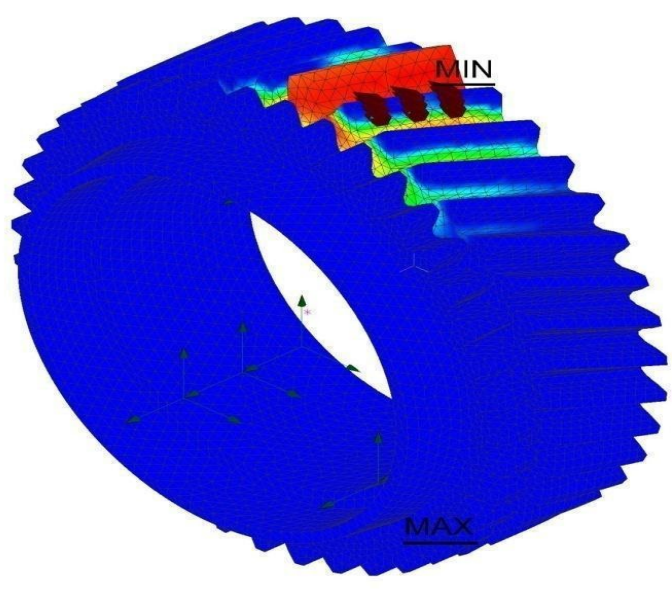

б)

Рис. 7. Коефіцієнта запасу по текучості

а) шестерня постійного зачеплення; б) шестерня п’ятої передачі

Таблиця 8 - Дані по коефіцієнту запасу міцності

\begin{tabular}{|c|c|c|c|c|}
\hline \multirow{2}{*}{ Найменування } & \multicolumn{2}{|c|}{ Шестерня 23 } & \multicolumn{3}{|c|}{ Шестерня 24 } \\
\cline { 2 - 5 } & Min & Max & Min & 1000 \\
\hline Коефіцієнт запас міцності & 4,609 & 100 & 69,79 & 19 \\
\hline
\end{tabular}

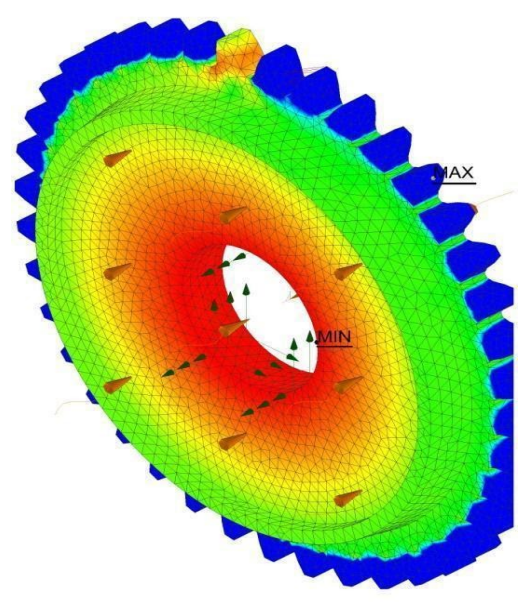

a)



б)

Рис. 8. Коефіцієнта запасу міцності:

a) шестерня постійного зачеплення; б) шестерня п'ятої передачі

Таблиця 9 - Результати розрахунку власних частот

\begin{tabular}{|c|c|c|c|c|}
\hline \multirow{2}{*}{$№$} & \multicolumn{2}{|c|}{ Шестерня 23 } & \multicolumn{2}{c|}{ Шестерня 24 } \\
\cline { 2 - 5 } & Частота [рад/сек] & Частота [Гц] & Частота [рад/сек] & 40996,65 \\
\hline 1 & 58548,72 & 9318,31 & 257589,54 & 41348,30 \\
\hline 2 & 58585,77 & 9324,21 & 259799,08 & 41422,58 \\
\hline 3 & 60709,15 & 9662,16 & 260265,80 & 41699,31 \\
\hline 5 & 67470,07 & 10738,19 & 262004,55 & 42414,44 \\
\hline
\end{tabular}




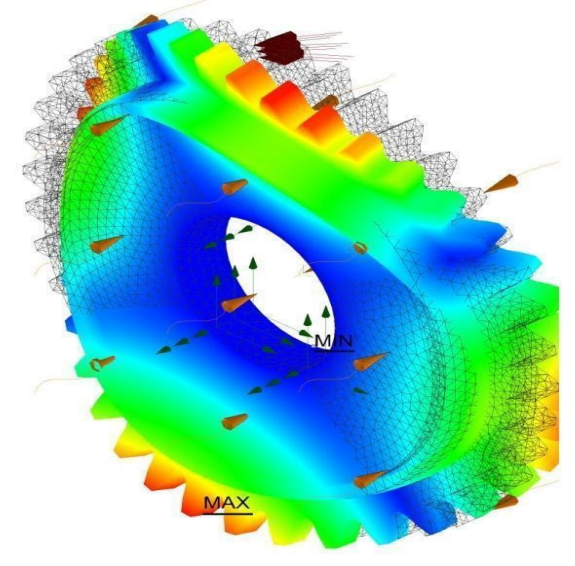

a)

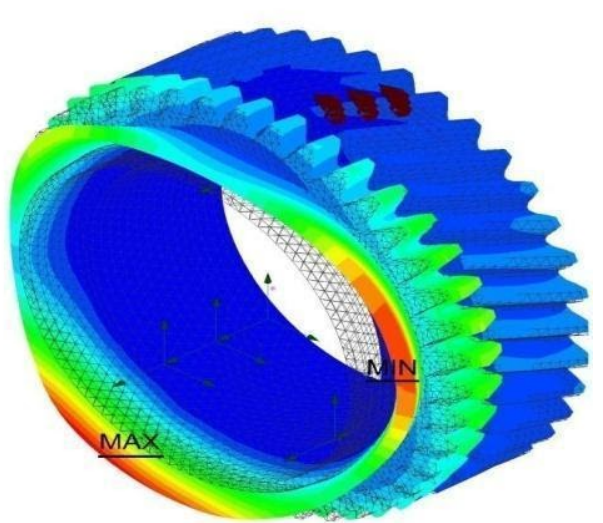

б)

Рис. 9. 5-я форма власних коливань:

а) шестерня постійного зачеплення; б) шестерня п’ятої передач

Також був проведений розрахунок коефіцієнта запасу по текучості, представлений (рис. 7) і (табл. 7). Він склав для шестерні постійного зачеплення 2,6 i 40 п'ятій передачі. Так як кут профілю зубів різний, то запас міцності по текучості розподіляється більш рівномірно в шестерні постійного зачеплення i під кутом в п'ятій передачі. Так як в шестерні 23 працюють всі зуби одночасно на подобу, шліцьового з'єднання, тому 3 огляду на їх кількість сумарний коефіцієнт запасу по міцності значно більше. В шестерні 24 за рахунок нахилу зуба і більшої площі також достатній, 3 огляду на те, що в постійному зачепленні знаходяться не всі зуби. Виходячи 3 цього коефіцієнти запасу по текучості у обох шестерень не дуже різняться. Був проведений розрахунок коефіцієнта запасу по міцності (рис. 8), (табл. 8). Аналіз отриманих результатів показує, що мінімальний коефіцієнт запасу міцності по шестерні п'ятої передачі рівний 8,6 і шостий передачі більше 60 задовольняє всім вимогам безпеки. Також виконано розрахунок власних частотних [Гц], і кутових частотних (циклічних частот, рад/сек) коливань (табл. 9), і показана 5-я форма коливань

(рис. 9). Аналіз частотних коливань показав, їх незначний вплив на деталі i механізми при конструюванні трьох вальної коробки. Так як більшість своїх частот виведена 3 робочого діапазону дії вібрації. Найчастіше виникнення резонансу є вкрай небажаним в плані забезпечення надійності деталей. Багаторазове збільшення амплітуд коливань при резонансі і викликані цим високі рівні напруг - одна 3 основних причин виходу з ладу виробів, експлуатованих в умовах вібраційних навантажень. Одним із способів $\epsilon$ протидія резонансам. Резонанси спостерігаються на частотах, близьких до частот власних коливань конструкції. Тому, якщо оцінити спектр власних частот конструкції, то можна зі значною часткою ймовірності спрогнозувати ризик виникнення резонансів у відомому діапазоні частот зовнішніх впливів. Для повного або значного зменшення ймовірності появи резонансів необхідно, щоб більша частина нижніх власних частот конструкції не лежала в діапазоні частот зовнішніх впливів. Це також дозволить обійтися без застосування спеціальних віброізолюючих систем. При аналізі найчастіше використовують перші три форми коливань, які відображають практично всі можливі варіанти реакції структури. У проведеному аналізі більша частина власних частот виведена 3 робочого діапазону дії вібрації, що забезпечує повну безпеку від руйнування при роботі деталей в механізмі коробки передач.

Висновки. Спроектована коробка забезпечує виведення крутного моменту на будь-яку сторону, що дозволить використовувати іiі, як у задньомоторних, передньопривідних i повнопривідних конструкціях автомобілів. Має високий ККД, як у двохвальних коробок, а також має передачу 3 передавальним відношенням одиниця, що з'єднує первинний та вихідний вал коробки.

В роботі виконано дослідження напружено-деформованого стану шестерні постійного зачеплення і п'ятої передачі, спроектованої трьохвальної коробки, для цього використовувався метод кінцевих елементів, який дає змогу досить повно врахувати геометричні форми та реальні умови роботи передачі, розподілу зовнішніх навантажень, а також фізичні властивості використовуваних матеріалів. 


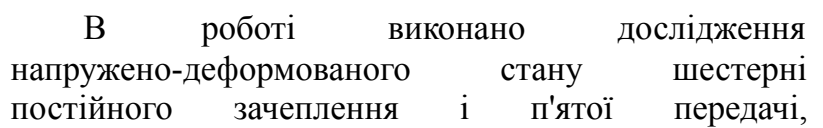
спроектованої трьохвальної коробки, для цього використовувався метод кінцевих елементів, який дає змогу досить повно врахувати геометричні форми та реальні умови роботи передачі, розподілу зовнішніх навантажень, а також фізичні властивості використовуваних матеріалів. За допомогою програмного середовища КОМПАС 3D V16, була розроблена тривимірна модель досліджуваних деталей. Розрахунок був виконаний із застосуванням системи APM FEM. Створена сітка кінцевих елементів, що дозволило 3 досить високою точністю провести розрахунок проектованих шестерень. Також був виконаний розрахунок міцності, який показує, як розподіляється навантаження по всіх поверхні зубів, i максимальні навантаження, створювані на ї поверхні. Проведено розрахунок мінімальних коефіцієнтів запасу по міцності і текучості, який задовольняе вимогам 3 безпеки. Виконано розрахунок власних частотних коливань і кутових частот. Аналіз, показує їх незначний вплив на деталі і механізми при конструюванні трьохвальної коробки. Проведене статистичне дослідження шестерень постійного зачеплення та п’ятої передачі проектованої трьохвальної коробки передач вказує на те, що в подальшому даний тип дослідження може бути застосований до інших навантажених елементів.

\section{Список літератури}

1. Кудрявцев В.Н. Зубчатые передачи. МАШГИЗ, Москва,
$1957,260 \mathrm{c}$.

1. Кудрявцев В.Н. Зубчатые передачи. МАШГИЗ, Москва,
1957, 260с.
2. Автомобили ВАЗ-2110, ВАЗ-21102, ВАЗ-2111, Ремонт и техническое обслужсивание. $180 \mathrm{c}$.

3. Гаспарянц Г.А. Конструкиия, основы теории и расчета автомобиля: Учебник для машиностроительных техникумов по специальности «Автомобилестроение» -

М.: Машиностроение, 1978. - 351с.

4. Киркач Н.Ф., Баласанян Р.А. Расчет и проектирование деталей матин. Учеб пособие для техн вузов. 3-е изд., перераб. и доп. - Х.: Основа, 1991.

5. Конструирование и расчет автомобиля: Учебник для студентов втузов специальности «Автомобили и тракторы» / П.П. Лукин, Г.А. Гаспарян и др. - М.: Машиностроение, 1984. - 376c.

6. Осепчугов В.В., Фрумкин А.К. Автомобили: Анализ конструкций, элементы расчета. Учебник для студентов вузов специальности «Автомобили и автомобильные хозяйства». М.: Машиностроение, 1989. - 304c.

7. APM FEM Система прочностного анализа для КОМПAC-3D /URL: http://www.apm.ru

\section{References (transliterated)}

1. Kudryavtsev V.N. Gears. MASHGIZ, Moscow, 1957, 260p. 2. Cars VAZ-2110, VAZ-21102, VAZ-2111, Repair and maintenance. $180 \mathrm{p}$.

3. Gasparyants G.A. Design, fundamentals of the theory and calculation of the car: A textbook for engineering schools in the specialty "Automotive" - M .: Engineering, 1978.- 351p.

4. Kirkach N.F., Balasanyan R.A. Calculation and design of machine parts. Textbook for technical universities. 3rd ed., Revised. and add. - X .: Basis, 1991.

5. Design and calculation of the car: Textbook for students of technical colleges of the specialty "Cars and Tractors" / P.P. Lukin, G.A. Gasparyan et al. - M.: Mechanical Engineering, 1984. 376p.

6. Osepchugov V.V., Frumkin A.K. Cars: Structural analysis, calculation elements. A textbook for university students majoring in "Automobiles and motor vehicles." M: Mechanical Engineering, 1989.- 304p.

7. APM FEM Strength Analysis System for KOMPAS-3D / URL: http://www.apm.ru

Надійила (received) 02.09.2020

Відомості про авторів / Сведения об авторах / About the Authors

Островерх Олександр Олегович (Островерх Александр Олегович, Оstroverkh Alexander Olegovich) - кандидат технічних наук, Національний технічний університет «Харківський політехнічний інститут», доцент кафедри автомобіле- та тракторобудування; м. Харків, Україна; e-mail: ostrov.sasha@gmail.com 